\title{
Unusual Recovery of Banded Black Duck
}

by E. Kuyt, Canadian Wildlife Service, Fort Smith, N.W.T.

Banding gives useful information about the longevity of birds. On the strength of banding records, F. H. Kortright (1942. Ducks, geese and swans of North America), for example, gives age records for many species of waterfowl - Trumpeter Swan 321/2 years, Canada Goose 33 years, Mallard 20 years, Black Duck seven and 10 years, Blue-winged Teal four years, etc.

On June 9, 1963 we collected a Black Duck (Anas rubripes) at Lockout Point, Thelon River, N.W.T. This bird, one of a pair, carried band No. 577-39092. The band had become badly worn and it cracked on being flattened out prior to submission to the U.S. Fish and Wildlife Service. It turned out that the duck was banded on August 31, 1955, as an immature male in Newport, Vermont, by that state's Fish and Game Department. The bird had thus almost completed its eighth year. Small wonder that the band was badly worn!

Black Ducks are not common in the Thelon area. We see only the cccasional pair or small flock of three or four birds. We have not found any nests or young of the Black Duck there in four summers. Perhaps these ducks only come there to moult as do the Canada Geese in the Thelon River area.

\section{Banding Recovery of Great Gray Owl}

by A. F. Oeming, Alberta Game Farm; Edmonton

A recent banding return from the U.S. Fish and Wildlife Service informed me that a Great Gray Owl (Strix nebulosa) banded (No. 49856703 ) by me as a four-week-cld juvenile. on May 30, 1954 had been recovered 70 miles to the north near Drayton Valley in September, 1963, by R. Hamilton, Thorsby, Alberta. The bird was one of two banded at a nest site some 50 miles west of Rocky Mountain House, Alberta, during an intensive preliminary Great Gray Owl. life history study.

In February, 1963, I recovered a female Snowy Owl (Nyctea nyctea) previously banded, March, 1954, in the same area, Andrew, Alberta. In fact this bird was less than two miles from the original banding site and her weight ( 5 lbs. 9 ozs.) had dropped only one ounce. The plumage was faded, but the bird was as physically vigorous as I recall her being in 1954 .

These returns indicate that life spans cf northern owls may be surprisingly long and that the Great Gray Owl may never wander far frcm its birth region and that Snowy Owls (Can. Field Nat. 72: 171-172, 1958 ) inexplicably return to the same wintering grounds.

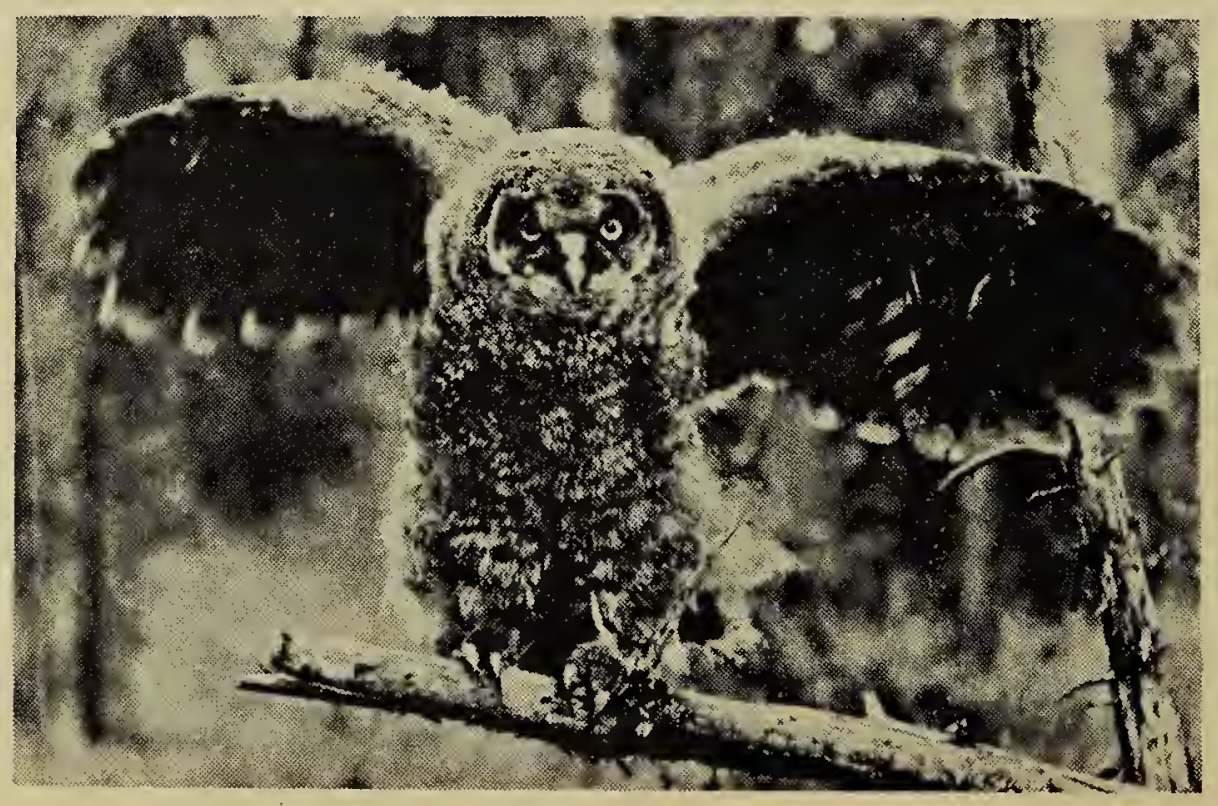

